\title{
DNA Sequence Analysis of $d t x R$ Gene (Partial) of Corynebacterium diphtheriae Causing Diphtheria in Jawa and Kalimantan Islands, Indonesia
}

\author{
Sunarno $^{1, *}$, Yuanita Mulyastuti ${ }^{2}$, Nelly Puspandari ${ }^{1}$, Kambang Sariadji $^{1}$ \\ ${ }^{1}$ Center for Biomedical and Basic Technology of Health, National Institute of Health Research and Development, JI Percetakan Negara 29, Jakarta \\ ${ }^{2}$ Department of Microbiology, Faculty of Medicine, Universitas Brawijaya, Jl. Veteran, Ketawanggede, Malang \\ *Corresponding author. E-mail: no_nar@yahoo.com
}

Received date: Oct 2, 2016; Revised date: Apr 5, 2017; Accepted date: May 4, 2017

\section{Abstract}

B ACKGROUND: $d t x R$ gene is a global regulator that can be used as a marker for detection of Corynebacterium diphtheriae (C. diphtheriae) and it is also a representative tool for mapping purpose (molecular typing) of this bacteria. The aim of this study was to analyze the DNA sequences of partial $d t x R$ gene of $C$. diphtheriae causing diphtheria in some region of Indonesia. DNA sequence analysis was used to verify the accuracy of the in-house multiplex polymerase chain reaction (PCR) method that used for detection of $C$. diphtheriae in the clinical specimen as well as a preliminary study to determine the strain diversity of $C$. diphtheriae circulating in Indonesia.

METHODS: Ten PCR products targeting the $d t x R$ gene that have been detected as positive $C$. diphtheriae previously by in-house multiplex PCR used as samples in this study. The DNA sequencing carried out by Sanger method and the

\section{Introduction}

Diphtheria is a vaccine preventable disease. The use of diphtheria toxoid vaccine globally reduces the prevalence of diphtheria cases significantly.(1,2) However, the largest diphtheria outbreak since the introduction of vaccination was observed in Russia and the Newly Independent States of the former Soviet Union on the 1990s with at least 150,000 morbidities and more than 4,000 mortalities. This outbreak makes a great influence worldwide. $(3,4)$ World sequence data was analyzed by Bioedit software offline and basic local alignment sequence typing (BLAST) online.

RESULTS: All of DNA sequence analyzed in this study were similar or identical to the $d t x R$ gene sequence data of $C$. diphtheriae registered in GenBank. Within the 162 nucleotides (base 150-311) of $d t x R$ gene that analyzed, at least 2 clonals were found among 10 samples. Substitutions of 2 nucleotides (base 225 and 273) was detected, both were silent mutation.

CONCLUSION: Ten partial DNA sequences of $d t x R$ genes in this study verify the accuracy of in-house multiplex PCR which used to identify the bacteria causing diphtheria in the clinical specimen. The DNA sequences also represent the existing diversity of the bacteria causing diphtheria circulating in Indonesia.

KEYWORDS: $d t x R, C$. diphtheriae, diphtheria, Indonesia

Indones Biomed J. 2017; 9(2): 91-8

Health Organization (WHO) data showed that diphtheria is still a global health problem, especially in developing countries, including Indonesia. In fact, in the last few year Indonesia was ranked $2^{\text {nd }}$ and $3^{\text {rd }}$ cases of diphtheria globally after India and Nepal.(5) Currently, the spread of diphtheria cases have reached almost all provinces in Indonesia, from Aceh to Papua province with a quite high case fatality rate (CFR).(6)

Diphtheria is caused by a group of bacteria known as potentially toxigenic Corynebacteria, consisting of Corynebacterium diphtheriae (C. 
diphtheriae), Corynebacterium ulcerans (C. ulcerans), and Corynebacterium pseudotuberculosis (C. pseudotuberculosis).(7) These bacteria produce diphtheria toxin through lysogenic process by a bacteriophage carrying the tox gene.(8-10) In diphtheria toxin synthesis process, tox gene is regulated/repressed by a set of genes in the bacterial chromosome known as the diphtheria toxin repressor/ regulator $(d t x R)$ gene.

The DtxR protein encoded by $d t x R$ gene would bind to the tox gene promoter-operator (tox-PO). Furthermore, it will inhibit the transcription process of diphtheria toxin synthesis.(11) These processes influenced by the presence of metal ions, particularly iron (Fe) as the co-factor. Therefore, the iron metals level in the bacterial environment will affect diphtheria toxin production both in vitro and in vivo. $(12,13)$ The $d t x R$ gene is also referred as a global regulator or metalloregulator as its function in regulating several genes involved in iron uptake and transport, including Siderophore or Corynebactin. $(14,15)$

The DtxR is a $25 \mathrm{kDa}$ protein that consists of 226 amino acid residues. DtxR proteins are divided into three domains, helix-turn-helix (residues 1-73), metal binding site (residues 74-140), and Src homology 3 (SH-3) (residues 147-226). The region between N-terminal (helix-turn-helix and metal binding site) and C-terminal, residues 125-139 consist of tether region rich in amino acid Proline.(16) N-terminal is the region which binds to the tox- $P O$ gene and the metal ion mostly located. The binding of DtxR - tox-PO occurred by 2 dimerization at the almost opposite palindromic region that involves several amino acid residues. Otherwise, the binding of the metal ion occurred at 2 different site, primary and ancillary region that also involves several amino acid residues. $(17,18)$ SH-3 domain is located at the C-terminal and the contribution of this domain remains unclear although some study predicts its role as the dimerization stabilizer by forming hydrogen binding.(19)

The $d t x R$ is a multifunction gene, hence it can be used as a genetic marker for detection and mapping (molecular typing) of bacteria causing diphtheria. Several studies has shown the potency of $d t x R$ gene as a marker of $C$. diphtheriae and also for C. ulcerans and C. pseudotuberculosis. $(20,21)$ In addition, $d t x R$ gene also used for typing of $C$. diphtheriae causing diphtheria outbreak in Russia and Ukraine based on the mutation analysis by polymerase chain reaction, singlestrand conformation polymorphism (PCR SSCP) and direct sequencing. $(22,23)$ This study aimed to analyze the DNA sequences of $10 C$. diphtheriae $d t x R$ partial genes that have detected by in-house multiplex PCR method in the clinical specimen from diphtheria cases and close contacts in some regions of Indonesia. In this study, we use sequence analysis to verify the accuracy of in-house multiplex PCR method to identify the bacteria causing diphtheria, as well as a preliminary study to determine the strains diversity of $C$. diphtheriae circulating in Indonesia.

\section{Methods}

\section{Samples}

This study focused on analyzing DNA sequence of partial $d t x R$ gene. The samples were 10 PCR product consist of $C$. diphtheriae $d t x R$ gene fragment. The origin of samples were clinical specimen (throat swab) from suspected diphtheria cases and close contact that sent to the Research Laboratory of Infectious Diseases Prof. dr. Sri Oemijati for the bacteria causing diphtheria detection and identification. The clinical specimens were collected and sent to the laboratory in 20132014 period. Amies transport medium in $2-8^{\circ} \mathrm{C}$ temperature was used for the bacterial viability maintenance in the specimen transportation.

Identification of the bacteria causing diphtheria was performed by conventional methods and in-house multiplex PCR assay with 5 pairs of PCR primer targeting $d t x R$ and tox gene as we described previously.(21) The bacterial DNA for in-house multiplex PCR samples was extracted from clinical specimen by using QiaAmp commercial kit (Qiagen, California, USA) according to the instructions of the manufacturer with a few modification.(24) Another PCR by monoplex technic was performed on the $C$. diphtheriae positive samples only. The second PCR assay was performed using the same method with in-house multiplex PCR assay except the primer pair used were only one primer pair corresponding to $d t x R$ gene (dtxR1_F and dtxR1_R). Ten products of second PCR were then used as a sample for DNA sequencing analysis of $d t x R$ gene in this study.

\section{DNA Sequencing and Data Analysis}

DNA sequencing was conducted by Sanger method. Sap Exo-IT kits were used to purify the genomic DNA. The PCR master mix contained $1 \mu \mathrm{L}$ template DNA (PCR product), $1.6 \mu \mathrm{M} d t x R$ primer (dtxR1_F and dtxR1_R), $0.5 \mu \mathrm{L}$ premix BigDye Terminator $\mathrm{v}, 3.1,3 \mu \mathrm{L}$ sequencing buffer $\mathrm{v}, 3.1$ and $\mathrm{ddH}_{2} \mathrm{O} 4.5 \mu \mathrm{L}$. The sequencing was performed by using 3500 Series Genetic Analyzers (Applied Biosystems, California, USA) with following conditions: $96^{\circ} \mathrm{C}$ for 1 minute followed by 25 cycles of $96^{\circ} \mathrm{C}$ for 10 seconds, $50^{\circ} \mathrm{C}$ for 5 seconds and $60^{\circ} \mathrm{C}$ for 4 seconds. 
The data obtained from the sequencing process was analyzed using Bioedit software offline and BLAST software online based on reverse complement sequence alignment (forward and reverse) and graphs chromatography. DNA sequences of $d t x R$ gene were compared with reference strain (PW8) data and also with the previously published sequences registered in GenBank (www.ncbi.nlm.nih.gov/ genbank/).

\section{Results}

\section{Samples}

The characteristics of the sample showed that the samples were collected from different area with 2 variations of bacteria (Table 1). All samples (product of second PCR) were separated by gel electrophoresis with gel red staining (Biotium, California, USA) and analyzed by Geldoc XR plus (Biorad, California, USA) (Figure 1). All samples were expected to have amplification product with $162 \mathrm{bp}$ band corresponding to primer pair targeting dtxR gene (dtxR1_F and dtxR1_R) and without nonspecific bands.

\section{DNA Sequencing and Data Analysis}

DNA sequence variation was shown among 10 samples and the DNA profile of $d t x R$ gene in all samples similar with reference strain (PW8) (Table 2, 3). There were two point mutation within $162 \mathrm{bp}$ amplified fragment of $d t x R$ genes (base 150-311) among 10 samples. In addition, twelve different mutations were also detected in another sequence registered on GenBank.

\section{Discussion}

The samples used in this study were originally collected from three provinces in Indonesia that located in two islands, Jawa and Kalimantan, as shown in Table 1. These samples only grouped by island territory because the population mobility that influences the disease's transmission is relatively more common among the regions on one island. Ministry of Health data showed that several diphtheria cases found in Kalimantan during 2014. The highest cases found in West Kalimantan, followed by South Kalimantan and East Kalimantan, meanwhile no diphtheria case found in Central Kalimantan. Based on the data, diphtheria cases in Jawa Island dominated by East Java, followed by Banten, West Java, Jakarta, and Central Java in the same year. No diphtheria case found in Jogjakarta.(6) Since Indonesia consist of 34 provinces, these three provinces do not represent Indonesia, but at least those data can be used as a preliminary description of the bacteria that cause diphtheria in Indonesia.

Table 1. Characteristic of samples by origin and bacterial toxigenicity.

\begin{tabular}{lccc}
\multicolumn{1}{c}{ Origin of Sample (Island) } & Toxigenic & Non-Toxigenic & Number \\
\hline Kalimantan & 6 & 1 & 7 \\
Jawa & 1 & $2 *$ & 3 \\
\hline Total & 7 & $\mathbf{3}$ & $\mathbf{1 0}$ \\
\hline *1 person is residing temporarily & & &
\end{tabular}

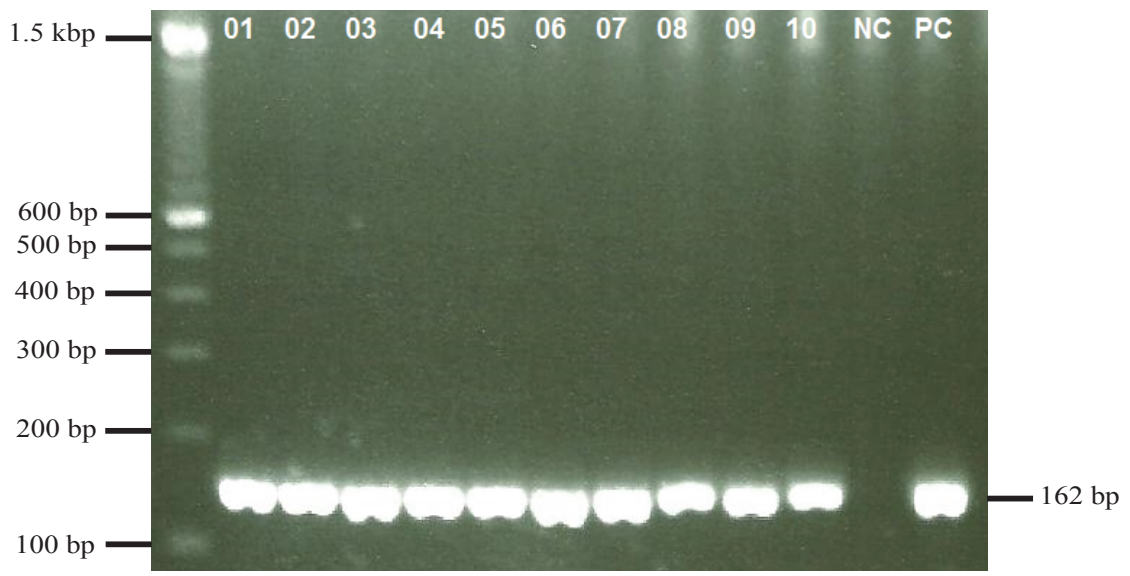

Figure 1. The result of second PCR: 100bp DNA ladder (line1), sample 1-10 (line 2-11), negative control dd $\mathrm{H}_{2} \mathrm{O}$ (line 12), positive control (line 13). 
Table 2. DNA sequences profile of partial $d t x R$ genes (base $150-311$ ) of 10 C. diphtheriae sample in this study.

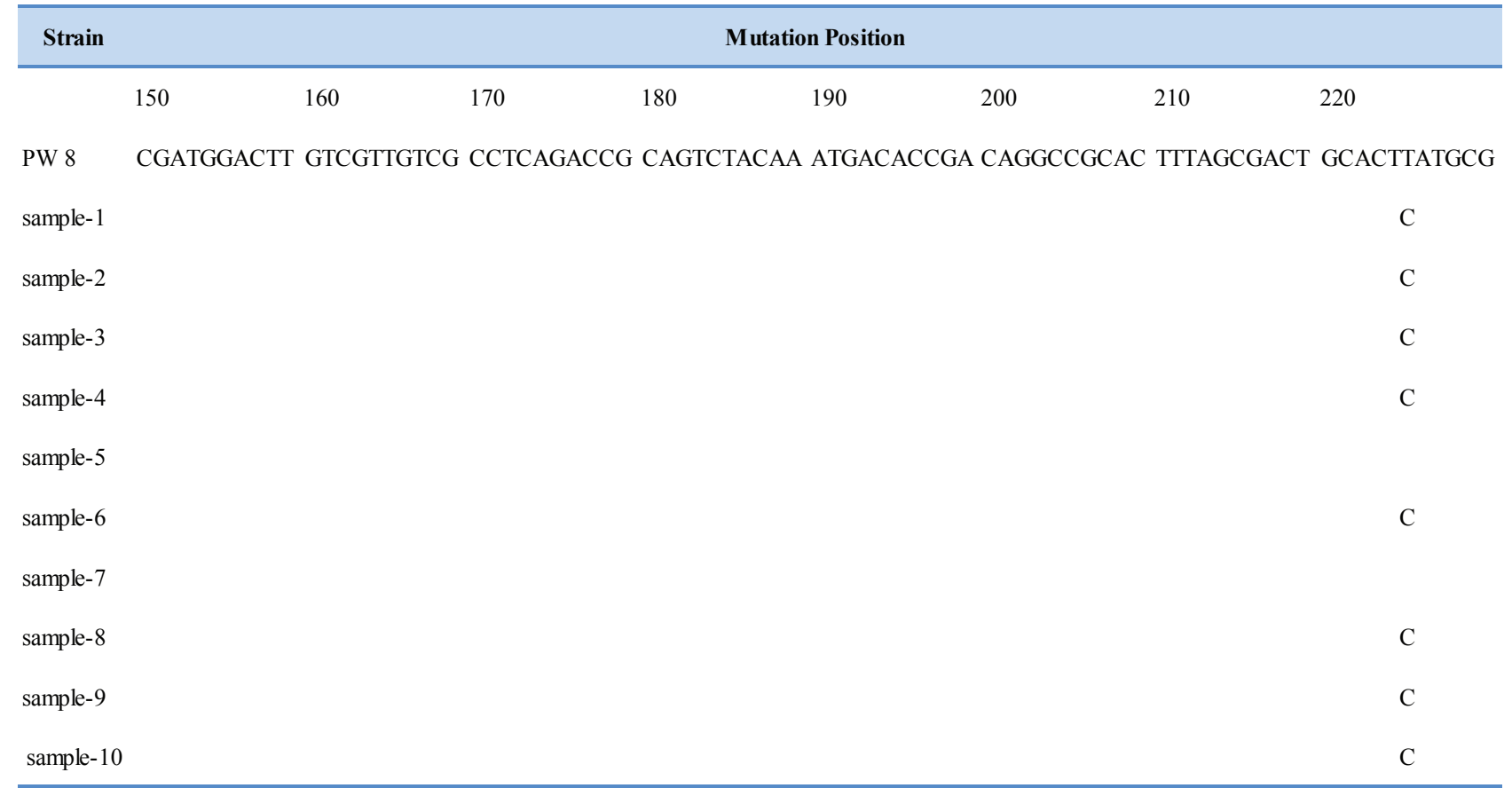

\begin{tabular}{ccccccccc}
\hline \multicolumn{7}{l}{ Strain } & \multicolumn{7}{c}{ Mutation Position } \\
\hline & 230 & 240 & 250 & 260 & 270 & 280 & 290 & 300
\end{tabular}

PW 8 GTAAACATCG CTTAGCTGAg CGCCTTCTTA CCGATATCAT TGGCCTAGAT ATCAATAAag TTCACGATGA AGCCTGCCGC TG

\begin{tabular}{lr} 
sample-1 & $\mathrm{T}$ \\
sample-2 & $\mathrm{T}$ \\
sample-3 & $\mathrm{T}$ \\
sample-4 & $\mathrm{T}$ \\
sample-5 & $\mathrm{T}$ \\
sample-6 & $\mathrm{T}$ \\
sample-7 & $\mathrm{T}$ \\
sample-8 & $\mathrm{T}$ \\
sample-9 & $\mathrm{T}$ \\
sample-10 & $\mathrm{T}$ \\
\hline
\end{tabular}

Samples are grouped by bacterial toxigenicity, toxigenic and nontoxigenic. In this study, we did not obtain the non-toxigenic tox gene-bearing (NTTB) strains, which is defined as genotypically tox positive but do not express the protein. $(25,26)$ The bacterial toxigenicity determine bacterial pathogenicity and pathology of disease. Toxigenic strain produces diphtheria toxin that responsible for systemic clinical symptom of disease.(27) C. diphtheriae toxigenic are major diphtheria causative agent in developing countries, included Indonesia. (21)

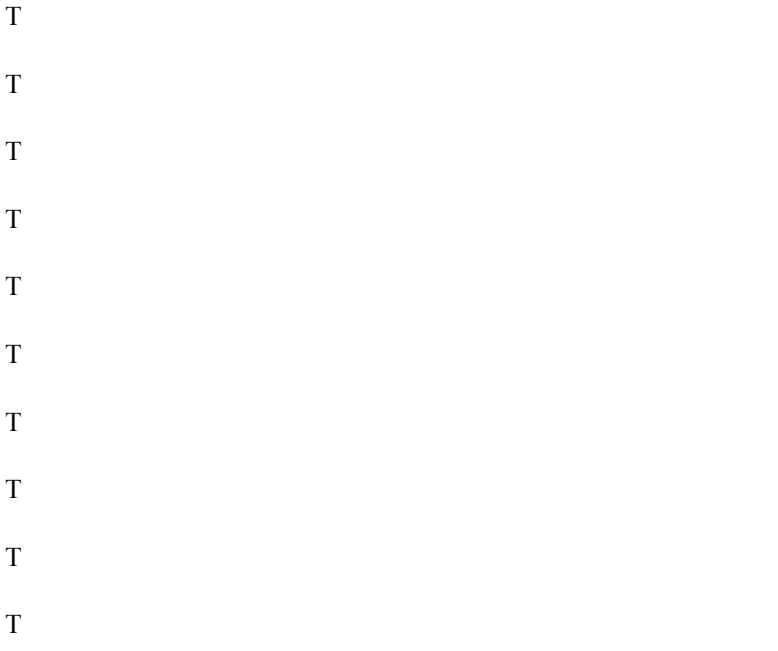

In other hands, nontoxigenic strain usually relates to diphtheria with mild symptom, such as pharyngitis. Even though, nontoxigenic diphtheria strain cannot be neglected. Nontoxigenic diphtheria may cause severe disease, for instance, endocarditis and bacteremia.(28-30) This strain also can transform to toxigenic strain. One of sample that analyzed in this study is $d t x R$ gene of nontoxigenic diphtheria strain, obtained from clinical specimen of hospitalized patient with mild diphtheria symptom. Samples were not classified by subtype (gravis, mitis, intermedius 
Table 3. Mutation analysis of the DNA sequences of $d t x R$ genes from samples and data registered in GenBank.

\begin{tabular}{|c|c|c|c|c|c|c|c|c|c|c|c|c|}
\hline \multirow[t]{2}{*}{ Strain } & \multicolumn{12}{|c|}{ Mutation Position } \\
\hline & 180 & 195 & 198 & 204 & 207 & 210 & 225 & 234 & 246 & 252 & 273 & 309 \\
\hline PW 8 (consensus) & $\mathrm{C}$ & A & G & $\mathrm{C}$ & $\mathrm{C}$ & $\mathrm{T}$ & $\mathrm{T}$ & A & $\mathrm{T}$ & $\mathrm{C}$ & $\mathrm{C}$ & $\mathrm{C}$ \\
\hline sample-1 & . & . & . & & . & . & $\mathrm{C}$ & . & & . & $\mathrm{T}$ & . \\
\hline sample-2 & . & . & . & & . & . & $\mathrm{C}$ & . & . & . & $\mathrm{T}$ & . \\
\hline sample-3 & & . & . & . & . & & $\mathrm{C}$ & & . & . & $\mathrm{T}$ & \\
\hline sample-4 & . & . & . & & . & . & $\mathrm{C}$ & . & . & . & $\mathrm{T}$ & . \\
\hline sample-5 & . & . & . & & . & . & . & . & . & . & $\mathrm{T}$ & . \\
\hline sample-6 & . & . & . & & . & & $\mathrm{C}$ & . & & . & $\mathrm{T}$ & . \\
\hline sample-7 & & & & . & & . & & & . & & $\mathrm{T}$ & \\
\hline sample-8 & . & . & . & & . & . & $\mathrm{C}$ & . & & . & $\mathrm{T}$ & . \\
\hline sample-9 & . & & . & & . & . & $\mathrm{C}$ & . & & . & $\mathrm{T}$ & . \\
\hline sample-10 & & . & & . & & & $\mathrm{C}$ & & . & & $\mathrm{T}$ & \\
\hline C.d.96/10 & . & . & . & & . & . & . & . & . & . & & . \\
\hline 16194 & . & . & . & & . & . & . & . & . & . & & . \\
\hline FRC0004 & . & & . & & . & . & . & . & . & . & & . \\
\hline 11852 & & & & . & & & & & & & . & \\
\hline 39091 & . & & . & & . & . & . & . & & . & & . \\
\hline 7275 & . & & . & & . & . & . & . & . & . & & . \\
\hline IR74 & & & & . & & & & & & & $\mathrm{T}$ & \\
\hline 6732 & . & . & . & & . & . & $\mathrm{C}$ & . & & . & $\mathrm{T}$ & . \\
\hline CORDTXRAB:173-853 & . & . & . & & . & . & . & . & . & . & $\mathrm{T}$ & . \\
\hline 9337 & . & . & . & & . & . & $\mathrm{C}$ & . & . & . & $\mathrm{T}$ & . \\
\hline CD95/407 & & & & . & & & $\mathrm{C}$ & & . & & $\mathrm{T}$ & \\
\hline C.d.96/552 & . & . & . & & . & & $\mathrm{C}$ & . & & . & $\mathrm{T}$ & . \\
\hline CD95/211 & . & . & . & & . & . & $\mathrm{C}$ & . & . & . & $\mathrm{T}$ & . \\
\hline IR125 & & & & . & & . & & & . & & $\mathrm{T}$ & \\
\hline CD95/305 & . & . & . & & . & & $\mathrm{C}$ & . & & . & $\mathrm{T}$ & . \\
\hline $2005-3187$ & . & G & . & & . & . & $\mathrm{C}$ & . & . & $\mathrm{T}$ & $\mathrm{T}$ & . \\
\hline 25298 & $\mathrm{~T}$ & G & A & $\mathrm{T}$ & $\mathrm{T}$ & G & $\mathrm{C}$ & G & A & . & & A \\
\hline 39077 & $\mathrm{~T}$ & G & A & $\mathrm{T}$ & $\mathrm{T}$ & G & $\mathrm{C}$ & G & A & . & . & A \\
\hline CORDTXRAC:208-888 & $\mathrm{T}$ & G & A & $\mathrm{T}$ & $\mathrm{T}$ & G & $\mathrm{C}$ & G & A & . & & A \\
\hline $\mathrm{HC} 02$ & . & . & . & & . & . & . & . & . & . & $\mathrm{T}$ & . \\
\hline $\mathrm{HC} 01$ & & & & . & & . & $\mathrm{C}$ & & . & . & $\mathrm{T}$ & . \\
\hline CDCE 8392 & . & . & . & & . & & C & . & & . & $\mathrm{T}$ & . \\
\hline 241 & . & . & . & & . &. & C & . & . & . & $\mathrm{T}$ & . \\
\hline 681-1361 & . & . & . & & . & . & . & . & . & . & $\mathrm{T}$ & . \\
\hline $31 \mathrm{~A}$ & & & . & . & . & . & . & & & . & $\mathrm{T}$ & . \\
\hline NCTC 13129 & . & . & . & & . & . & . & . & . & . & & . \\
\hline BH8 & . & . & . & & . & . & . & . & . & . & & . \\
\hline INCA 402 & & & . & . & . & . & . & & & . & . & . \\
\hline VA01 & . & . & . & & . & & & . & . & . & . & . \\
\hline HC04 & . & . & . & & . & . & . & . & & . & . & . \\
\hline $\mathrm{HC} 03$ & . & . & . & & . & . & . & . & & . & . & . \\
\hline C7 & . & . & . & & . & . & . & . & . & . & $\mathrm{T}$ & . \\
\hline CORDTXRAA:690-1370 & . & . & . & & & . & . & . & . & & $\mathrm{T}$ & . \\
\hline
\end{tabular}


and belfanti) because some samples only genotypically detected by PCR (undetected by conventional methods) hence it is impossible to identify the subtype.

DNA sequencing is widely used in molecular techniques, to define a genetic marker for organism detection and identification, including mapping purpose.(31) One of the objectives of DNA sequences analysis in this study is to verify the in-house multiplex PCR results that used for bacterial identification (C. diphtheriae, $C$. ulcerans and $C$. pseudotuberculosis) from clinical specimen that performed before.(21) The in-house multiplex PCR assay has some advantages compare with established methods. This is a new method and result confirmation by DNA sequencing carried out to ensure no mismatch in the amplification process. DNA sequence analysis using BLAST program and BioEdit software show that all samples have a similar or identical DNA sequence of C. diphtheriae PW8 (consensus sequence) and several strains registered on GenBank. The in-house multiplex PCR have been applied for the bacteria causing diphtheria identification in the Research Laboratory of Infectious Diseases Prof. dr. Sri Oemijati routinely.

Beside for PCR result confirmation, DNA sequence of partial $d t x R$ gene are used for initial description of the existing bacteria causing diphtheria diversity in Indonesia. Table 2 and 3 showed that there are at least two clones of bacteria among 10 samples analyzed. Two samples with Cytosine (C) $\rightarrow$ Thymine (T) substitution at 273 base position are originally from Jawa Island. Otherwise, 8 samples with $\mathrm{T} \rightarrow \mathrm{C}$ substitution at 225 base position and $\mathrm{C}$ $\rightarrow$ T substitution at 273 base position are from Kalimantan Island (7 samples) and from Jawa Island (1 sample), who reside temporarily. Two types of the DNA sequence are similar to the data that already registered on GenBank. Seven samples from Kalimantan (sample 1, 2, 3, 4, 6, 8 and 9) and 1 sample from Jawa (sample 10) are similar to data from strain 6732, 9337, CD95/407, Cd96/552, CD95/211, CD95/305, HC01, CDCE 8392 and 241. Meanwhile, 2 sample from Jawa (samples 5 and 7) are similar to data from strain CORDTXRAB: 173-853, IR125, HC02, 681-1361, 31A, C7 and CORDTXRAA: 690-1370.

These results showed that disease transmission occurred more between regions in the same island, as predicted previously. Further analysis (complete DNA sequence) of available data in GenBank revealed that there are difference pattern between strains 6732, 9337, CD95/407, Cd96/552, CD95/211, CD95/305, HC01 and CDCE 8392, as well as strains CORDTXRAB: 173-853, IR125, HC02, 681-1361, 31A, C7 and CORDTXRAA: 690-
1370. From these facts, if the same analysis applied to the sample used in this study, we assume that there would be more variation of DNA sequences.

DNA is the blueprint of amino acid sequences in protein, the DNA sequence of dtxR gene can be used to predict the amino acid sequences of DtxR protein. The amino acid sequence can be used to determine bacterial virulence indirectly, mainly related to the repressor functions of $d t x R$ in diphtheria toxin synthesis.(32-34) Prediction of the amino acid translated from DNA sequence in this study cover 53 amino acid residues (51 to 103) from start codon (ATG) of $d t x R$ genes. Fifty-three amino acids (residue 51-103) that made up of 162 bases analyzed in this study (starting from the start codon) were DGLVVVASDR SLQMTPTGRT LATAVMRKHR LAERLLTDII GLDINKVHDE ACR. Some of the amino acid position in the range of 51 to 103 that need more concern and proven may affect the repressor function including amino acid residues 50, 72, 77, 79, 80, $83,84,88,98,100,102$ and 104.(17,34,35)

Most of the amino acid residues roles in metal ion binding in the metal binding site domain. Amino acid residue 102 (Cysteine) has a central role in metal ion binding. Substitution in these positions, except with Aspartic Acid, will inactive the repressor and toxin production would not affect by the environment $\mathrm{Fe}$ level.(36) Cysteine in that position is the only Cysteine that assembles DtxR proteins. DNA mutation in 10 observed sample and also in Genbank data are the silent mutation (no amino acid substitutions) which is predicted will not change the dtxR function, although further study is still needed for confirmation.(37)

It should be underlined that the result obtained in this study is only preliminary data about the bacterial causing diphtheria variety and the disease's transmission, and also about amino acid that arrange DtxR protein structure. Further analysis using more reliable genotyping method, such as multilocus sequences typing (MLST) and ribotyping should be performed for more sample.(38-40)

\section{Conclusion}

DNA sequences of partial dtxR genes in this study verify the accuracy of in-house multiplex PCR used to identify the bacteria causing diphtheria. In addition, these results illustrate the genetic diversity of C. diphtheriae strains circulating in Jawa and Kalimantan Islands, Indonesia. This study also ensures that there are no amino acid substitutions encoded by dtxR gene related to the base nucleotide 
mutations observed. The Limitations of this study is the limited number of samples has not been able to describe the reality of genetic diversity of strains circulating in Indonesia diphtheria.

\section{Acknowledgments}

Our thanks go to all those involved in this research, in particular the staff of Bacteriology and Virology Laboratories, Center for Biomedical and Basic Technology of Health, National Institute of Health Research and Development, Jakarta.

\section{References}

1. Wagner KS, White JM, Lucenko I, Mercer D, Crowcrft NS, Neal S, et al. Diphtheria in the postepidemic period, Europe, 2000-2009. Emerg Infect Dis. 2012; 18: 217-25.

2. Guilfoile PG. Deadly Diseases and Epidemics: Diphtheria. New York: Chelsea House Publishers; 2009.

3. Hardy IRB, Dittmann S, Sutter RW. Current situation and control strategies for resurgence of diphtheria in newly independent states of the Former Soviet Union. The Lancet. 1996; 347: 1739-44.

4. Galazka A. The changing epidemiology of diphtheria in the vaccine era. J Infect Dis. 2000; 181: S2-9. doi: 10.1086/315533.

5. WHO. Diphtheria reported cases. [updated 2014 Mar 17; cited 2015 May 22]. Available from: http://apps.who.int/immunization monitoring/globalsummary/timeseries/tsincidencediphtheria.html.

6. CDC Indonesia, Ministry of Health. Diphtheria Surveillance Data -Monthly Integrated VPD Report. 2014 [unpublished material].

7. Burkovski A. Diphtheria and its etiological agent. In: Burkovski A, Editor. Corynebacterium diphtheriae and Related Toxigenic Species. New York: Springer; 2014. p.1-16.

8. Sekizuka T, Yamamoto A, Komiya T, Kenri T, Takeuchi F, Shibayama $\mathrm{K}$, et al. Corynebacterium ulcerans 0102 Carries the Gene Encoding Diphtheria Toxin on A Prophage Different from the C.diphtheriae NCTC 13129 Prophage. BMC Microbiology. 2012; 12:72. doi: 10.1186/1471-2180-12-72.

9. Selim SA, Mohamed FH, Hessain AM, Moussa IM. Immunological Characterization of diphtheria toxin recovered from Corynebacterium pseudotuberculosis. Saudi J Biol Sci. 2016; 23: 282-87.

10. Oram M, Woolston JE, Jacobson AD, Holmes RK, Oram DM. Bacteriophage-based vectors for site-specific insertion of DNA in the chromosome of Corynebacteria. Gene. 2007; 392: 53-62.

11. Murphy JR, Michel JL, Teng M. Evidence that the regulation of diphtheria toxin production is directed at the level of transcription. $\mathrm{J}$ Bacteriol. 1978; 135: 511-6.

12. Tchorbanov AI, Dimitrov JD, Vassilev. Optimization of casein-based semisintetic medium for growing of toxigenic Corinebacterium diphtheriae in a fermenter. Can J Microbiol. 2004; 50: 821-6.

13. Allen CE, Burgos JM, Schmitt MP. Analysis of novel iron-regulated surface-anchored hemin-binding proteins in Corynebacterium diphtheriae. J Bacteriol. 2013; 195: 2852-63.
14. Brune I, Werner H, Huser AT, Kalinowski J, Puhler A, Tauch A. The $\mathrm{dtxR}$ protein acting as dual transcriptional regulator directs a global regulatory network involved in iron metabolism of Corynebacterium glutamicum. BMC Genomic. 2006; 7: 21. doi: 10.1186/1471-21647-21.

15. Merchant AT, Spatafora GA. A Role for the dtxR family of Metalloregulators in Gram-positive Pathogenesis. Molecular Oral Mocrobiology. 2014; 29: 1-10. doi: 10.1111/omi.12039.

16. Qiu X, Verlinde CLMJ, Zhang S, Schmitt MP, Holmes RK, Hol WGJ Three-dimensional structure of the diphtheria toxin repressor in complex with divalent cation co-repressors. Structure. 1995; 3: 87100.

17. White A, Ding X, VanderSpek JC, Murphy JR, Ringe D. Structure of the metal-ion-activated diphtheria toxin repressor/tox operator complex. Nature. 1998; 394: 502-6.

18. D'Aquino JA, Tetenbaum-Novatt J, White A, Berkovitch, Ringe D. Mechanism of metal ion activation of the diphtheria toxin repressor dtxR. Proc Natl Acad Sci USA. 2005; 102: 18408-13.

19. Marin V. Domain-domain interactions on the activation pathway of diphtheria toxin repressor protein (dtxR) [Dissertation]. Florida: Florida State University; 2005.

20. Torres LDFC, Ribeiro D, Hirata R Jr, Pacheco LGC, Souza MC, Ribeiro MG, et al. Multiplex polymerase chain reaction to identify and determine the toxigenicity of Corynebacterium spp with zoonotic potential and an overview of human and animal infections. Mem Inst Oswaldo Cruz. 2013; 108: 272-9.

21. Sunarno. Development of multiplex PCR for identify species and toxigenicity (toxigenic, non-toxigenic and NTTB) potentially toxigenic Corynebacteria [Dissertation]. Jakarta: Universitas Indonesia; 2015.

22. Nakao H, Pruckler JM, Mazurova IK, Narvskaia OV, Glushkevich T, Marijevski VF, et al. Heterogeneity of diphtheria toxin gene, tox, and its regulatory element, dtxR, in Corynebacterium diphtheriae strains causing epidemic diphtheria in Russia and Ukraine. J Clin Microbiol. 1996; 34: 1711-16.

23. Nakao H, Mazurova IK, Glushkevich T, Popovic T. Analysis of heterogeneity of Corynebacterium diphtheriae toxin Gene, tox, and its regulatory element, dtxR, by direct sequencing. Res Microbiol. 1997; 148: 45-54.

24. Sunarno, Muna F, Fitri N, Malik A, Karuniawati A, Soebandrio A Metode cepat ekstraksi DNA Corynebacterium diphtheriae untuk pemeriksaan PCR. Bulet Penelit Kesehat. 2014; 42: 85-92.

25. Eisenberg T, Kutzer P, Peters M, Sing A, Contzen M, Rau J. Nontoxigenic tox-bearing corynebacterium ulcerans infection among game animals, Germany. Emerg Infect Dis. 2014; 20: 44852.

26. Zakikhany K, Neal S, Efstratiou. Emergence and molecular characterization of non-toxigenic tox gene-bearing Corynebacterium diphtheriae Biovar mitis in the United Kingdom, 2003-2012. Euro Surveill. 2014; 19: 20819.

27. Nursyamsi-Agustina N, Wahyutomo R, Hapsari MMDEAH, Wahjono H. Tonsilopharingitis diphtheriae complicated with diphtheritic myocarditis in 13 years old girl at DR Kariadi Hospital Semarang-Indonesia. J Clin Microbiol Infect Dis. 2014; 1: 6-16.

28. Menon T, Senthilkumar S, Pachaiyappan P. Native valve endocarditis caused by a non-toxigenic strain of Corynebacterium diphtheriae. Indian J Pathol Microbiol. 2010; 53: 899-900.

29. Zasada AA, Baczewska-Rej M, Wardak S. An increase in nontoxigenic Corynebacterium diphtheriae infections in Poland - molecular epidemiology and antimicrobial susceptibility of strains isolated from past outbreak and those currently circulating 
in Poland. Int J Infect Dis. 2010; 14: e907-e912. doi: 10.1016/j. ijid.2010.05.013.

30. Wojewoda CM, Koval CE, Wilson DA, Chakos MH, Harrington SM. Bloodstream infection caused by nontoxigenic Corynebacterium diphtheriae in an immunocompromised host in the United States. J Clin Microbiol. 2012; 50: 2170-2.

31. Dasgupta MG, Dharanishanthi V, Agarwal I, Krutovsky KV. Development of genetic markers in Eucalyptus species by target enrichment and exome Sequencing. PLOS One. 2015; 10: e0116528. doi: 10.1371/journal.pone.0116528.

32. Holmes RK. Biology and molecular epidemiology of diphtheria toxin and the tox gene. J Infect Dis. 2000; 181: S156-67.

33. Pohl E, Goranson-Siekierke J, Choi MK, Roosild T, Holmes RK Hol WGJ. Structure of three diphtheria toxin repressor (dtxR) variant with decreased repressor activity. Acta Cryst. 2001; D57: 619-27.

34. Wang Z, Schmitt MP, Holmes RK. Characterization of mutations that inactivate the diphtheria toxin repressor gene (dtxR). Infect Immun. 1994; 62: 1600-8.

35. Love JF, vanderSpek JC, Marin V, Guerrero L, Logan TM, Murphy JR. Genetic and biophysical studies of diphtheria toxin repressor
(E175K) support a multistep model of activation. Proc Natl Acad Sci USA. 2003; 101: 2506-11.

36. Tao X, Schiering N, Zeng H, Ringe D, Murphy JR. Iron, dtxR and the regulation of diphtheria expression. Mol Microbiol. 1994; 14: 191-7.

37. Zheng S, Kim H, Verhaak RGW. Silent mutations make some noise. Cell. 2014; 156: 1129-31.

38. Wagner KS, White JM, Neal S, Crowcroft NS, Kupreviciene N, Paberza R, et al. Screening for Corynebacterium diphtheriae and C.ulcerans in patients with upper respiratory tract infections 20072008: A multicentre europian study. Clin Microbiol Infect. 2010; 17: 519-25.

39. Bolt F, Cassiday P, Tondella ML, Dezoysa A, Sing A, Zasada A, et al. Multilocus sequence typing identifies evidence for recombination and two distinct lineages of Corynebacterium diphtheriae. J Clin Microbiol. 2010; 48: 4177-85.

40. Konig C, Meinel DM, Margos G, Konrad R, Sing A. Multilocus sequence typing of Corynebacterium ulcerans provides evidence for zoonotic transmission and for increased prevalence of certain sequence types among toxigenic strains. J Clin Microbiol. 2014; 52: 4318-24. 